Journal of Contemporary Research in Social Sciences

ISSN : 2641-0249

Vol. 2, No. 3, pp. 57-67

2020

Publisher: Learning Gate

DOI: 10.33094/26410249.2020.23.57.67

(C) 2020 by the authors; licensee Learning Gate

\title{
Steps toward Smooth Graduation of Bangladesh from Least Development Countries
}

\author{
Md Ziaur Rahman \\ Assistant Secretary (Junior Diplomat), Ministry of Foreign Affairs, Government of the People's Republic of Bangladesh. \\ Email:ziasociologydu@gmail.com \\ Monalisa Sony \\ Assistant Judge, Bangladesh Judicial Service, People's Republic of Bangladesh. \\ Md Shakhawat Hossen Rubel \\ Senior Assistant Secretary, Ministry of Public Administration, Dhaka, People's Republic of Bangladesh. \\ Masudul Alam \\ Assistant Director, Directorate of Government Accommodation, Bangladesh Secretariat, Dhaka, Bangladesh. \\ Rokeya Akther Liza \\ Department of English Literature, Bangladesh University of Professionals, Dhaka, Bangladesh.
}

Received: 1 September 2020; Revised: 23 September 2020; Accepted: 9 October 2020; Published: 26 October 2020

\begin{abstract}
Purpose: Bangladesh is one of the least developed countries of the world according to the Committee of Development Policy, a panel of the UN General Assembly. This study aims to explore the status of economic graduation and development of Bangladesh from the Least Development Countries (LDC) category to Middle Income Country (MIC). This study intends to contribute the debate regarding the graduation status of Bangladesh and briefly clarifies the difference of classification by highlighting implementation challenges, obstacles after graduation, preparedness and measures for gaining better graduation. Methodology: A qualitative approach has been used in this study. This study is based on secondary data obtained from various reliable sources. The study also has consulted various policy papers, journal articles, report and working papers of international organizations. Results: The study reveals that the country has attained the three-vulnerability criteria- GNI per capita, Human Asset Index, and Economic Vulnerability Index (EVI) for graduating the LDC status. According to the procedure, Bangladesh has been declared a time of three years period from 2018 to 2021 for upgrading the current progress. Originality/Value: This study also focuses on the benefits of crossing the least development country (LDC) line, the implications of the economy in middle income country (MIC) status and the risk factors. Practical implications: The study suggests that a continuous effort should be given by the government by gaining experience from another developed country to reduce risk factors to ensure sustention of current progress not only for the observation period but also for extensive development.
\end{abstract}

Keywords: Economic development, graduation, LDC, MIC, Bangladesh.

\section{Introduction}

Bangladesh is a promising Lower Middle-Income Country aimed to graduate from LDC by 2021 which is a very auspicious year for the country-the golden jubilee of its independence. The Least 
Developed Countries (LDC) has to meet certain criteria to graduate like gross national income (GNI), Human Assets Index (HAI) and the Economic Vulnerability Index (EVI) (O'Neill, 1984). Graduation enhances the image of a country as well as its credit ratings and improves investors' perceptions in both the public and the private sector (Sarker, Wu, Alam, \& Shouse, 2020). Graduation has economic implications and involves and risk factors like withdrawal of International Support Measures, reduction of preferential market access and TRIPS complications (Drabo \& Guillaumont, 2017). Graduation is an irreversible track for Bangladesh (Sarker \& Rahman, 2019). Bangladesh requires strong international support in terms of stirring necessary knowledge, technologies, and capacities (Sarker, Yang, Lv, Enamul, \& Kamruzzaman, 2020). Bangladesh should focus on proper administrative arrangements to face new opportunities and challenges (Sarker, Hossin, Min, \& Aktaruzzaman, 2018). As part of Bangladesh's initiatives, a team led by Principal Coordinator (SDGs Affairs) visited the United Nations Committee for Development Policy (UNCDP) Secretariat, representatives of Committee for Development Policy (CDP) came to Dhaka and A High-level Meeting on 'Achieving Sustainable Graduation for the LDCs' held in Dhaka arranged to discuss sustainable graduation and smooth transition (Chowdhury, 2013). On 16 March 2018, Committee for Development Policy (CDP) of the United Nations has formally confirmed the suitability of Bangladesh for promoting from the least developed countries (LDCs) to developing nations (Chen, Wang, \& Kamruzzaman, 2020; Kamruzzaman, He, \& Peng, 2019; Sarker et al., 2020).

For the smooth transition from LDC to MIC, Bangladesh government should take necessary measures to cope with the changing economic scenario and some of them have been recommended. Bangladesh has a current GNI of 233.79 billion USD with a population of 163.7 million (Khatun, Pervin, \& Rahman, 2018). According to 2018 triennial review, Bangladesh per capita GNI is $\$ 1274$, the value of HAI is 73.2 in a graduation threshold of 66 or above, the value of EVI is 25.2 in a graduation threshold of 32 or below (CDP, 2018). Bangladesh has a lot of growth potentials; its economy is growing fast with on an average $7 \%$ growth rate during last decade (Khatun, 2018), it has exceeded the graduation thresholds of Economic Vulnerability Index (EVI) in addition to Human Asset Index (HAI). It has also met the graduation threshold of Gross National Income (GNI) per capita before the recent triennial review of the UN in 2018. To graduate from LDC by 2021, Bangladesh has to increase investment as well as need continuation of the trade preferences and benefits that it continues to enjoy (Chowdhury, 2013).

In 2011, the government of Bangladesh aimed to graduate from LDC and to reach the status of MIC by 202 1; miraculously Bangladesh achieved World Bank's "lower middle income" status six years earlier than the targeted time (Akanda, 2015). Now it is a preparation time for Bangladesh before embracing graduation as it is going to bring a lot of benefits and impediments altogether. There is a long debate regarding the graduation status of Bangladesh. This study intends to contribute in this debate and briefly clarifies the difference of classification by addressing the research questions like what is the current economic status of Bangladesh as middle-income country (MIC) after graduation from LDC? and what are the challenges and possible ways of sustainable graduation?

The rest part of the article is arranged as the second section deals with the review of the literature, third section deals methodology and fourth section deal with findings and discussion focusing graduation status of Bangladesh from LDC to MIC and recommendation for solving possible challenges. The final section concludes the article.

\section{Literature Review}

\subsection{Least Developed Countries (LDCs)}

The Least Developed Countries (LDCs) are economically vulnerable countries with low-level human assets. They are the poorest and weakest countries in the world. In 1971, the United Nations general assembly adopted the LDC category to provide international assistance to a special group of developing countries. Initially, there were only 25 members, who were the most vulnerable and disadvantaged countries of the world. These countries had low-income levels, had structural weaknesses 
to develop and required certain measures to address problems (Biswas, 2018). At present, there are 47 countries listed as LDCs. Among them 33 are in African, 13 in Asia and the Pacific and 1 in Latin America (CDP, 2018). There are more than 880 million living in people in LDCs, they comprise 12 percent of the world's population (UNCTAD, 2016). Nevertheless, they contribute to less than 2 percent of world GDP and about 1 percent of global trade in goods. There are many reasons for their low level of socio-economic development for example, weak human and institutional capacities, scarcity of domestic financial resources and unequally distributed income etc (Kamruzzaman et al., 2019). Besides, poor governance, political unrest and both internal and external conflict are common there (Chen et al., 2020). They fall into the trap of a vicious cycle of poverty due to low productivity, low investment, and vulnerability to external terms-of-trade shock (Bhattacharya \& Borgatti, 2012). Some of them have been able to diversify into the manufacturing sector especially in labor-intensive industries like textiles, clothing etc (Table 1).

Table-1.

List of Least Developed Countries with a year of inclusion.

\begin{tabular}{|c|c|c|c|c|}
\hline \multicolumn{3}{|c|}{ Africa (33) } & \multirow{2}{*}{$\begin{array}{l}\text { Asia and the Pacific } \\
\text { (13) } \\
\text { Afghanistan (1971) }\end{array}$} & \multirow{2}{*}{$\begin{array}{c}\text { Latin } \\
\text { America (1) } \\
\text { Haiti (1971) }\end{array}$} \\
\hline Angola (1994) & $\begin{array}{c}\text { Guinea-Bissau } \\
(1981)\end{array}$ & $\begin{array}{c}\text { Somalia } \\
(1971)\end{array}$ & & \\
\hline Benin (1971) & Lesotho (1971) & $\begin{array}{l}\text { South Sudan } \\
(2012)\end{array}$ & Bangladesh (1975) & \\
\hline Burkina Faso (1971) & Liberia (1990) & Sudan (1971) & Bhutan (1971) & \\
\hline Burundi (1971) & Madagascar (1991) & $\begin{array}{c}\text { Tanzania } \\
(1971)\end{array}$ & Cambodia (1991) & \\
\hline $\begin{array}{l}\text { Central African } \\
\text { Republic (1975) }\end{array}$ & Malawi (1971) & Togo (1982) & East Timor (2003) & \\
\hline Chad (1971) & Mali (1971) & $\begin{array}{l}\text { Uganda } \\
(1971)\end{array}$ & Laos (1971) & \\
\hline Comoros (1977) & Mauritania (1986) & $\begin{array}{c}\text { Zambia } \\
(1991)\end{array}$ & Myanmar (1987) & \\
\hline $\begin{array}{c}\text { Democratic Republic } \\
\text { of Congo (1991) }\end{array}$ & Mozambique (1988) & & Nepal (1971) & \\
\hline Djibouti (1982) & Niger (1971) & & Yemen (1971) & \\
\hline Eritrea (1994) & Rwanda (1971) & & Kiribati (1986) & \\
\hline Ethiopia (1971) & $\begin{array}{l}\text { Sao Tome and } \\
\text { Principe (1982) }\end{array}$ & & Solomon Island (1991) & \\
\hline Gambia (1975) & Senegal $(2000)$ & & Tuvalu (1986) & \\
\hline Guinea (1971) & Sierra Leone (1982) & & Vanuatu (1985) & \\
\hline
\end{tabular}

\subsection{The criterion of Least Developed Countries (LDCs)}

The UN General Assembly (GA) and the Economic and Social Council (ECOSOC) authorized the Committee for Development Policy (CDP) to review the situations of LDCs. In every three years, they suggest policy on the inclusion and graduation of the eligible country based on some criteria like GNI per capita, Human Assets Index (HAI), and Economic Vulnerability Index (EVI). Based on the inclusion or graduation thresholds countries become eligible to enter or leave the LDC category (Drabo \& Guillaumont, 2017). Usually, the thresholds are set higher than the original thresholds. These criteria represent long-term structural handicaps and they are measured using fundamental indicators. Based on a three-year average GNI per capita, the inclusion threshold is set and which the World Bank describes for detecting low-income countries (Sarker, Khatun, \& Alam, 2019). To determine inclusion and 
graduation eligibility CDP uses absolute thresholds for GNI per capita, the Human Assets Index (HAI) $\&$ Economic Vulnerability Index (EVI). Table 2 mentions the inclusion and graduation criteria.

Table-2.

Inclusion and Graduation Thresholds in 2018.

\begin{tabular}{c|c|c|c}
\hline Criteria & GNI per capita & Human Asset Index & Economic Vulnerability Index \\
\hline Inclusion & $\$ 1,025$ and below & 60 and below & 36 and above \\
\hline $\begin{array}{c}\text { Graduation } \\
\text { "Income only" } \\
\text { graduation }\end{array}$ & $\$ 1230$ and above & 66 and above & 32 and below \\
\hline
\end{tabular}

\subsection{Middle-Income Countries (MICs)}

Middle-income countries (MICs) are those countries, which are categorized by the World Bank based on their income level. It uses these categories for the operational and analytical purposes of classifying economies. Earlier Middle-income countries were referred to as developing countries. In 2016, the World Bank decided to drop the term as this term poorly identifies its status. Middle-income countries are divided into "lower-middle-income countries" and "upper-middle-income countries" (Table 3). According to 2019 fiscal year, the countries with a GNI per capita $\$ 996$ and $\$ 3895$ are lower-middleincome countries and the countries with a GNI per capita $\$ 3896$ and $\$ 12055$ are upper-middle-income countries (World Bank, 2018). The World Bank as the basis for this classification per capita uses GNI by considering it as the single best indicator of economic capacity and progress.

LDC and MIC are two different classifications to describe a country's economy Table 3. The United Nations (UN) General Assembly and the World Bank respectively use the terms. The Committee for Development Policy (CDP) of the UN Economic and Social Council holds a country to the LDC category based on the above-mentioned three categories while the World Bank uses the MIC term for its lending process. Technically, a country can be LDC and MIC at the same time as LDC requires graduation in HAI \& EVI along with the per capita GNI. Therefore, a country can have high income and still be a Least Developed Country because of vulnerability to external shocks (Akanda, 2015). As of July 2015, the low-income threshold was $\$ 1,045$ or less Bangladesh crossed this "lower-middle-income" threshold of $\$ 1045$ six years ago and joined the lower-middle-income country class on July 1, 2015 (World Bank, 2018). However, the accomplishment did not gain political momentum until 2011 when Bangladesh targeted the graduation from LDC in 2021, the golden jubilee of the country's independence. The graduation from the LDC group can be achieved in 2024 if the country is able to meet all the technical requirements in the coming years.

Table-3.

Middle Income Country (MIC) Indicator.

\begin{tabular}{c|c|c}
\hline Indicator & Lower Middle-Income Countries & Upper-Middle-Income Countries \\
\hline GNI per capita & Between $\$ 996$ and $\$ 3895$ & Between $\$ 3896$ and $\$ 12055$ \\
\hline
\end{tabular}

\section{Methodology}

A qualitative approach has been used in this study. This study is based on secondary data obtained from various reliable sources. This kind of methodology is used by some other researchers to conduct a similar analytical study (Akanda, 2015; Bhattacharya \& Borgatti, 2012; Kumar, 2014). Secondary data from United Nations Conference on Trade and Development (UNCTAD), United Nations General Assembly (UNGA), United Nations Development Programme (UNDP), World Bank, Committee for Development Policy (CDP), newspapers, reports, and articles have been used in this research. The study also has consulted various policy papers, journal articles, report and working papers of international organizations like UNDP, World Bank, UNGA, UNCTAD, and national organizations like CDP, BER, 
and various report of the government of Bangladesh. It has tried to include very recent data from all possible sources to expedite the argument.

\section{Findings and Discussion}

\subsection{LDC Graduation Process}

In every 3 years, the Committee for Development Policy (CDP) reviews the list of LDCs. It recommends for inclusion in and graduation from the category based on the specific criterion and related indicators. The Recommendations are not only based on the criteria scores. They consider complementary country-specific information, for example, Department of Economic and Social Affairs (DESA) impact assessment and United Nations Conference on Trade and Development (UNCTAD) vulnerability profile etc. They also consider the views of the government. To transform into MIC, the country must be met CDP's graduation thresholds for any two of the three criteria in two consecutive triennial reviews (Sarker et al., 2020). Otherwise, the country needs to meet the income-only criterion. It means that the gross national income (GNI) per capita of the country is at least twice the graduation threshold in two consecutive triennial reviews.

\subsection{Impacts of Graduation}

\subsubsection{Benefits of Graduation to MIC Status}

The image of a country increases after graduation. For example, credit rating, investment, and remittance. In the case of Bangladesh, graduation would give a better credit rating, allowing it to borrow more cheaply on world markets. At present, the country is ranked as Ba3 by Moody's rating agency which is below investment grade and assigns Bangladesh's bond the 'high-yield' or 'junk' status, although the outlook is stable. The ranking is likely to increase after graduation. The country can take the opportunity to increase investment, as graduation will lead to some improvement in investors' perceptions of its attractiveness as a destination for investment especially Foreign Direct Investment (FDI). Remittances are likely to send through official channels and mobilize into Diaspora investment due to good macroeconomic performance and a reliable financial sector underlying graduation.

\subsubsection{Economic Implications of Graduation and Risk Factors}

There are huge-rang of potential implications to the economy of the country as promotion from the LDC class means the eligibility of the country's entree to LDC-specific ISMs (international support measures). LDCs enjoy 136 international support measures. Therefore, the country's LDCs graduations strategies need to consider the probable implications of phasing out of ISMs after graduation.

\subsubsection{External Financing and Development Assistance}

Reduction of access to external financing may cause balance-of-payments problems, which could put at risk the continuance of the progress. Graduation could have greater implications in terms of access to Official development assistance (ODA) and other concessional financing and it affects the cost of financing. However, in the case of multilateral donors, concessional financing windows are more important which is not affected by graduation (Shafi, Zoya, Song, \& Sarker, 2020). On the other hand, the development progress underlying graduation decreases the necessity of Official development assistance (ODA). As graduating countries miss access to LDC-specific funding sources, especially the LDC Fund, it will effect on financing for climate change adaptation. The country will also lose the benefits of the Investment Support Program for LDCs as foreign direct investment (FDI). The graduating country will also lose the scholarships and research grants to LDCs.

\subsubsection{Trade Preferences}

After graduation, the country faces the loss of easy market access under LDC-specific schemes i.e. the European Union's Everything but Arms (EBA) steps and concerns in the Global System of Trade Preferences (GSTP). The probable influence of losing LDC-specific business preferences is projected at 
\$4.2 billion yearly for LDCs (UN-OHRLLS, 2017). Agricultural commodities, textiles, and apparel export will be affected most because tariffs are generally highest for non-LDCs. Countries could experience a decline in export revenues due to the loss of market access. However, as other LDCs lose such access on graduation, the value of preferential market access increases. After graduation, the country will need to incur costs that are more indirect, it may rise from the opportunity loss for export divergence or entrance into the new market.

\subsubsection{Special and Differential Treatment (SDT)}

Access to all LDC-specific SDT (Special and Differential Treatment) provisions and technical assistance under WTO rules as well as WTO-compliant zonal business contracts, along with those meet by their business partners, will be lost by the graduating countries. These will affect policy space and flexibility and increase adjustment cost. A country like Bangladesh may face problem in terms of the TRIPS Agreement, especially in the Pharmaceuticals sector. Until 2033, all LDCs can produce patented drugs without first asking patent holders. This implementation period must be used for developing proper policy and strategies as well as and meeting the legal complexities.

\subsection{Graduation Process for Bangladesh from LDC to MIC 4.3.1. Sustainable Graduation}

Country's economic strength is more important than when a country graduate. A country should balance between economic and political priorities. The graduating country should take lessons from past graduation experiences. Bangladesh should make Impact Assessment and Vulnerability Profile carefully for a smooth transition strategy (Sarker et al., 2019). Before graduation, the country should focus on strong governance, macroeconomic management and prudent policies, the creation of an enabling environment for private and foreign investment, investment on public health and education and negotiate graduation depending on country circumstances etc (Shafi et al., 2020).

\subsubsection{Economic Graduation of Bangladesh}

Bangladesh, the largest least developed country (LDC) in terms of population and economic size, is currently seen as 'Development Miracle' in the world. The country witnessed remarkable progress in terms of social, economic and human indicators etc. It is going to leave the LDC category by 2024 driven by better health and education, lower vulnerability and economic progress etc. Graduation will bring some implications for the economy as well as many challenges (Cao, Sarker, \& Sun, 2019). For Example, various WTO provisions providing SDT will be withdrawn; various countries' Generalized System of Preferences (GSP) schemes will be withdrawn and preferential market access initiatives that are part of regional trade agreements (RTAs) will be withdrawn etc. Bangladesh needs to prepare itself well as it is going to step into a new, unknown space namely MIC (Middle-Income Countries). On 16 March 2018 in New York at the UN headquarter, The Committee for Development Policy (CDP), which is a United Nations panel, announced Bangladesh’s during a conference.

\subsubsection{Road Map for the Graduation of Bangladesh}

Bangladesh needs to map out the potential loss of benefits and adjust institutional and legal frameworks. Bangladesh must make necessary administrative arrangements to face new opportunities and potentials as well as challenges of being an LDC country. A National Task Force (NTF) has been formulated comprising high-level relevant stakeholders. It will formulate Policy guidance for conducting the Impact Assessment Study on graduation of Bangladesh and Identify priorities for implementing the sustainable graduation roadmap (Sarker et al., 2019). Another motto is to intensify monitoring and advocacy as well as coordinating with all stakeholders. Bangladesh's MIC graduation process is likely to follow the under mentioned stages including first meeting the eligibility criteria in 2018 to final monitoring in 2033 (Table 4). 
Table-4.

Graduation process of Bangladesh with the timeframe.

\begin{tabular}{c|l}
\hline Timeframe & Stages \\
2017 & $\begin{array}{l}\text { A team led by Principal Coordinator (SDGs Affairs) visited New York to } \\
\text { discuss with UNCDP Secretariat and other officials of UN HQ. }\end{array}$ \\
\hline $\begin{array}{c}\text { 20-24 March } \\
2017\end{array}$ & $\begin{array}{l}\text { Bangladesh Delegation led by the Secretary, Economic Relations Division } \\
\text { (ERD) participated in a meeting organized by United Nations Committee for } \\
\text { Development Policy (UNCDP). }\end{array}$ \\
\hline 16 March 2018 & $\begin{array}{l}\text { Bangladesh meets eligibility for the first time. UNCDP's official declaration } \\
\text { for the suitability of Bangladesh for first time graduating from the LDCs to } \\
\text { developing nations. }\end{array}$ \\
\hline March 2021 & $\begin{array}{l}\text { Bangladesh meets eligibility for the 2nd time, CDP recommends for } \\
\text { graduation to ECOSOC }\end{array}$ \\
\hline Eune/July'21 & ECOSOC endorses recommendation \\
\hline Late 2021 & $\begin{array}{l}\text { General Assembly endorses decision (Bangladesh officially becomes a } \\
\text { graduating country. Transition period normally 3 years) }\end{array}$ \\
\hline $2021-2024$ & Bangladesh prepares transition strategy \\
\hline 2022 & Annual reporting to and monitoring by CDP begins \\
\hline $2024(+/-)$ & Bangladesh ceases to be LDC \\
\hline $2024(+/-)$ & Bangladesh implements a transition strategy \\
\hline $2024-2027$ & Withdrawal of international support measures \\
\hline $2033(+/-)$ & Last CDP monitoring report \\
\hline
\end{tabular}

\subsubsection{Visit of UNCDP to Bangladesh}

In order to discuss Bangladesh's prospective promotion from the least developed country (LDC) category, The Committee for Development Policy (CDP) visited Dhaka from 9-12 October 2017. They met the officials from Ministry of Finance, Ministries of Planning, Ministry of Foreign Affairs, the Bangladesh Bureau of Statistics (BBS) and the Prime Minister's Office (PMO), Chamber of Commerce, garments association and the Centre for Policy Dialogue (CPD) (BSS, 2018). They discussed the route to graduation, the standards for graduation and a comprehensive review of the data used in the analysis of Bangladesh's LDC status. In the meeting, CDP Secretariat introduced public and private sector representatives to the capacity development undertaken by them related to LDC-specific International Support Measures (ISMs) and a new graduation platform developed by the secretariat (Khatun, 2018). The main purpose of this support service is to help graduating countries in better understanding the graduation process and develop better strategies. The Ministry of Foreign Affairs in collaboration with the UN Office of the High Representative for least developing countries (LDCs), Landlocked developing countries (LLDCs) and Small Island Developing States (SIDS) jointly organized the meeting (UNOHRLLS, 2017). In this meeting, 150 participants took part from different governments, United Nations agencies, international and regional organizations, civil society. Substantive discussions took place on various issues related to sustainable graduation and smooth transition including technicalities of the graduation criteria and the process, realization of the potential costs and challenges associated with LDC graduation (Islam, Rahman, Sarker, Sarker, \& Jianchao, 2020). It is done to prepare for addressing impending challenges of graduation by identifying appropriate policy measures knowledge sharing between recently graduated LDCs and those about to graduation (Zamir, 2018). This meeting will essentially help Bangladesh to unpack the details of the possible road ahead, potential effects and alternate options (Shafi, Sarker, \& Junrong, 2019). 


\subsubsection{Declaration of Bangladesh's Recent Eligibility to Graduate from LDC Bloc}

On 16 March 2018 in New York at the UN headquarter, The Committee for Development Policy (CDP), which is a United Nations panel, announced Bangladesh's during a conference (CDP, 2018). The CDP officially communicated this to the mission at a simple ceremony on 16 March. Two other countries have also become eligible to leave the LDC bloc. They are- Myanmar and Laos (UNDP, 2017). The main 3 criteria are GNI, Human Assets Index (HAI) and Economic Vulnerability Index (EVI) that have met by Bangladesh for having the eligibility to graduate from LDC to MIC.

\subsection{Bangladesh's Current Status and the Prospect}

Bangladesh has already met following all the three graduation criteria during the recent CDP review in 2018. In 2021, Bangladesh requires to meet all the major criteria again. Bangladesh may graduate from LDC status in 2024 after the endorsement from the ECOSOC and approval by the General Assembly. Bangladesh may enjoy LDC preferential treatment up to 2027 for the smooth transition Table 5 .

Table-5.

Current economic status of Bangladesh.

\begin{tabular}{c|c|c|c}
\hline Indicators & Threshold for 2018 & CDP Calculation & BBS Calculation \\
\hline GNI per capita & US $\$ 1230$ or above & US $\$ 1272$ & US $\$ 1271$ \\
\hline HAI & 66 or above & 72.8 & 72.9 \\
\hline EVI & 32 or Less & 25.0 & 24.8 \\
\hline
\end{tabular}

After the completion of Doha Round negotiation of the WTO, duty will reduce for all countries. Low or zero tariff access for exporting countries is available through bilateral trade agreements. Bangladesh needs faster progress and faster preparation is to withstand the impact of the elimination of various special and differential treatments. Following policy measures have been taken for Smooth Graduation Table 6.

Table-6.

Policy measures to address the challenges of graduation.

\begin{tabular}{l|l}
\hline Challenges & Plans/Policies/Strategies \\
\hline ODA \& SSC & $\begin{array}{l}\text { National Policy, Firming Finance for the } 7^{\text {th }} 5 \text { year plan and SDGs in } \\
\text { Bangladesh, Debt sustainability, Joint Cooperation Strategy 2010, LCG, Sectoral } \\
\text { Working Group. }\end{array}$ \\
\hline Climate Finance & $\begin{array}{l}\text { Bangladesh Climate Change Strategy and Action Plan (BCCSAP) 2009, Climate } \\
\text { Change Trust Act 2010, Bangladesh Climate Fiscal Framework 2014, Capacity } \\
\text { development of NIEs to access GCF. }\end{array}$ \\
\hline DRM & $\begin{array}{l}\text { NBR Modernization Plan 2011-2016, VAT and SD Act 2012, Customs Act 2014, } \\
\text { Development Surcharge \& Levy (Imposition \& Collection) Act 2015 }\end{array}$ \\
\hline Investment & National Industrial Policy 2016, Bangladesh Economic Zones Act 2010 \\
\hline Remittance & Welfare of expatriates and foreign employment policy 2016 \\
\hline Tariff and non- & Export Policy 2015-18, Diagnostic Trade Integration Study \\
\hline Connectivity & BBIN MVA, BIMSTEC, BCIM-EC \\
\hline Productivity & $\begin{array}{l}\text { National ICT Policy 2015, National Industrial Policy 2016, National Skill } \\
\text { Development Policy 2011, Skills development: a priority agenda for accelerated } \\
\text { growth. }\end{array}$ \\
\hline Governance & $\begin{array}{l}\text { National Integrity Strategy (NIS) 2012, and Annual Performance Appraisal } \\
\text { (APA). }\end{array}$ \\
\hline
\end{tabular}




\subsection{Recommendations for Sustainable Graduation of Bangladesh}

Bangladesh is the country to graduate based on all the three criteria of CDP. For sustainable graduation, Bangladesh needs to identify the manifestations of graduations, possible implications, and alternate scenarios effectively and efficiently (Sarker \& Rahman, 2019). This study recommends the following strategy which should be taken by the government for smooth graduation from LDC to MIC.

a) Promote regional economic cooperation and integration through four pillars viz. establishing an integrated market, strengthening seamless connectivity, enhancing financial cooperation and addressing shared risks and vulnerabilities (Chen, Sui, \& Kamruzzaman, 2019).

b) EU trade preferences to LDCs under the EBA are extended for 3 years after graduation from LDC status. Bangladesh needs to develop a strategy and negotiate with the EU so that it may benefit from Standard GSP or GSP+ properly after that period. For the smooth transition from GSP to $\mathrm{GSP}+$, the government should take the following measures:

c) Foreign Ministry can call for an inter-ministerial meeting with Prime Minister's Office (PMO), Ministry of Trade and Commerce, Ministry of Finance, Ministry of Planning, Ministry of Textile and comprehensively discuss the administrative reforms for achieving GSP+ scheme.

d) Ministry of Labour and Ministry of Law should work closely to undertake legislative changes to the Bangladesh Labour Act and the implementation rules to bring it in line with ILO standards.

e) Ministry of Foreign Affairs should take the lead for investment campaign throughout the world and create a positive image for Bangladesh. In this regard, the embassies should work more closely with multinational companies and different economic organizations for promoting our interest

f) Ministries should be more proactive in formulating policies regard to human rights, labor rights, and gender equalities as these are the prime concerns for achieving EU Generalized Scheme of Preferences $(\mathrm{GSP}+)$.

g) Bangladesh and other LDCs are exempted from patent protection for an extended period. Until 2033, Bangladesh is allowed to produce any patented medicines without taking prior permission from the innovator. After graduation, to protect Bangladesh's Pharmaceuticals Industry under TRIPS agreement Bangladesh would have to update its patent law, revise 1982 drugs control ordinance and take other necessary policy reform.

h) Bangladesh is an International Development Association (IDA) only country and if it's GNI per capita exceeds the operational threshold for a third consecutive year, the country will be classified as an IDA gap country starting in FY 19. This implies a higher interest rate than the interest-free IDA financing does. Bangladesh should seek to strengthen partner. Bangladesh should consider taking a transformative approach to LDC Graduation through domestic capital and blended finance.

i) Bangladesh should arrange Free Trade Agreement (FTA) with other countries, for example, Bangladesh- Sri Lanka Free Trade Agreement (FTA) forging 'strategic partnership' between sectors and industries i.e. in Apparel sector, IT/ITES, Logistics, and Trans-shipment etc. Strong implementation of international support measure- Bangladesh should leverage for UN/UNDP Support for the IPoA implementation.

j) Bangladesh should develop strategies and negotiate with International/UN bodies/DPs to continue adequate supports to sustain post-graduation status. Graduation strategy has to be synchronized with national development strategy, economic policy, policies on trade and financial investments, policies on education, employment, etc. It needs to be coordination with the seventh five-year plan and implementation of SDGs.

k) Bangladesh needs a well-functioning Science, technology, and innovation (STI) ecosystem (Chen et al., 2020). It should seek cooperation and avails the opportunities of Technology Bank. Bangladesh should reinvent the demographic dividend. Low Human capital should be turned into developed human capital. The country should focus on capacity building and service delivery. It needs to increase labor productivity through investments and innovation. It should focus on removing weak institutions and low-quality infrastructure, difficulties of Doing Business as well as manage land constraint and ensure good governance.

Journal of Contemporary Research in Social Sciences
ISSN : 264.1-0249
Vol. 2, No. 3, pp. $57-67,2020$
DOI: $10.33094 / 26410249.2020 .23 .57 .67$
C) 2020 by the authors; licensee Learning Gate


1) Bangladesh should maintain and its current momentum and foster economic growth by way of ensuring inclusive economic and social development and reducing of political unrest, over dependency on primary commodity, Terrorism, and violent extremism. It should also focus on enhancing Disaster Risk Management. Bangladesh should research on graduated countries and learn from their experiences. For example, Botswana strengthened multilateral ties for market access, Samoa deepened regional cooperation, Maldives tapped the EIF for trade capacity building support and Cape Verde established a consultative mechanism with donors for the smooth transition.

\section{Conclusion}

Bangladesh has a huge potential for economic growth. If these potentials are diverted to the right direction, Bangladesh can surely sustain the current growth rate, which is almost $7 \%$. It is clear that Bangladesh has crossed the threshold of the least developing country (LDC) with a considerable gap. Bangladesh should consider proper administrative arrangement, as graduation brings with it a variety of new opportunities and challenges, to sustain such progress. After graduation, LDC-specific support measures including financial assistance, international trade, and other general support measures will be withdrawn. The country might fall at great risk without the current facilities. Proactive engagement with major development partners from the beginning to negotiate ad-hoc provisional arrangements will help Bangladesh to reduce graduation costs and to face both the opportunities and challenges of Graduation. As Bangladesh's journey towards graduation is irreversible, it should also carefully address all the issues to strengthen its economy. Among them, export diversification is of great concern, as the country showed immense success in the field of investment, debt, and remittances however the lack of success in diversifying export has been a setback. The export basket is so much concentrated in RMG (Readymade Garments) sector that a fall in prices or imposition of tariff can bring about recession in garments, the biggest source of employment in the industrial sector. Moreover, graduation from LDC will leave the country out of quota-free and duty-free facilities. There is a major chance of facing increased tariff in the RMG sector. Therefore, diversification is necessary along with the enhancement of strategies.

\section{References}

Ahmed, T. N. (2018). LDC graduation_ scopes and challenges. The Newage, p. 8. Retrieved from: http://www.newagebd.net/article/37523/ldc-graduation-scopes-and-challenges.

Akanda, M. A. I. (2015). Has Bangladesh really come ahead of the LDCs? Journal of Social and Economic Development, 17(2), 223-240.Available at: https://doi.org/10.1007/s40847-015-0015-2.

Bhattacharya, D., \& Borgatti, L. (2012). An atypical approach to graduation from the LDC category: The case of Bangladesh. South Asia Economic Journal, 13(1), 1-25.Available at: https://doi.org/10.1177/139156141 101300101.

Biswas, R. (2018). The least developed countries: Opportunities and challenges. In R. Biswas (Ed.), Emerging Markets Megatrend (pp. 167-186). Berlin Heidelberg: Springer.

BSS. (2018). Celebration for graduation from LDC begins. The Dhaka Tribune, Retrieved from: https://www.dhakatribune.com/bangladesh/2018/03/22/celebration-graduation-ldc-begins.

Cao, Q., Sarker, M. N. I., \& Sun, J. (2019). Model of the influencing factors of the withdrawal from rural homesteads in China: Application of grounded theory method. Land Use Policy, 85, 285-289.Available at: https://doi.org/10.1016/j.landusepol.2019.04.013.

CDP. (2018). Report on the twentieth session (12-16 March 2018). Retrieved from: http://undocs.org/en/E/2018/33.

Chen, G., Sui, X., \& Kamruzzaman, M. M. (2019). Agricultural remote sensing image cultivated land extraction technology based on deep learning. Journal of the Faculty of Agronomy, 36(6), 2199-2209.

Chen, G., Wang, L., \& Kamruzzaman, M. M. (2020). Spectral classification of ecological spatial polarization SAR image based on target decomposition algorithm and machine learning. Neural Computing and Applications, 32(10), 54495460.Available at: https://doi.org/10.1007/s00521-019-04624-9.

Chowdhury, T. T. (2013). Graduation of Bangladesh as least developed countries (LDC) (pp. 1-33). Dhaka, Bangladesh: Bangladesh Institute of Development Studies.

Drabo, A., \& Guillaumont, P. (2017). Graduation from the category of least developed countries: Rationale,achievement and prospects (No. 208) (pp. 1-60). Working Paper, Series: Development Policies, FERDI Publications. 
Islam, M. D., Rahman, A., Sarker, M. N. I., Sarker, M. S., \& Jianchao, L. (2020). Factors influencing rice farmers' risk attitudes and perceptions in Bangladesh amid environmental and climatic issues. Polish Journal of Environmental Studies, 30(1), 1-11.Available at: https://doi.org/10.15244/pjoes/120365.

Kamruzzaman, M. M., He, W., \& Peng, X. (2019). Performance of relay assisted uplink wireless communication using multilayered STBC for multiple access channel. Telecommunication Systems, 71(3), 309-320.Available at: https://doi.org/10.1007/s11235-018-0493-6.

Khatun, F. (2018). Ldc graduation: What it means for Bangladesh. The dailystar. Retrieved from: https://www.thedailystar.net/opinion/macro-mirror/ldc-graduation-what-it-means-bangladesh-1550542.

Khatun, F., Pervin, S., \& Rahman, M. (2018). How to ensure smooth transition after LDC graduation. The Daily Star. Retrieved from: https://www.thedailystar.net/opinion/economics/how-ensure-smooth-transition-after-ldcgraduation-1552840.

Kumar, A. (2014). Domestic politics of Bangladesh and India-Bangladesh relations. Strategic Analysis, 38(5), 652-667.Available at: https://doi.org/10.1080/09700161.2014.941214.

O’Neill, H. (1984). HICs,MICs,NICs and LICs: Some elements in the political economy of graduation and differentiation. World Development, 12(7), 693-712.Available at: https://doi.org/10.1016/0305-750X(84)90082-2.

Sarker, M. N. I., Hossin, M. A., Min, W., \& Aktaruzzaman, M. (2018). Poverty alleviation of rural people through good governance in Bangladesh. The Journal of Social Sciences Research, 4(12), 547-555.Available at: https://doi.org/10.32861/jssr.412.547.555.

Sarker, M., Cao, Q., Wu, M., Hossin, M., Alam, G., \& Shouse, R. (2019). Vulnerability and livelihood resilience in the face of natural disaster: A critical conceptual review. Applied Ecology and Environmental Research, 17(6), 1276912785.Available at: https://doi.org/10.15666/aeer/1706_1276912785.

Sarker, M. N. I., Khatun, M. N., \& Alam, G. M. (2019). Islamic banking and finance: Potential approach for economic sustainability in China. Journal of Islamic Marketing, 1O(4), 1-2.Available at: https://doi.org/10.1108/JIMA-04-20190076.

Sarker, M. N. I., \& Rahman, M. Z. (2019). Geopolitical influence and trade between Bangladesh and India. Bangladesh Journal of Public Administration, 27(2), 70-83.

Sarker, M. N. I., Wu, M., Alam, G. M., \& Shouse, R. (2020). Administrative resilience in the face of natural disasters: Empirical evidence from Bangladesh. Polish Journal of Environmental Studies, 29(2), 1825-1837.Available at: https://doi.org/10.15244/pjoes/109527.

Sarker, M. N. I., Yang, B., Lv, Y., Enamul, M., \& Kamruzzaman, M. M. (2020). Climate change adaptation and resilience through big data. International Journal of Advanced Computer Science and Applications, 11(3), 533-539.Available at: https://doi.org/10.14569/IJACSA.2020.0110368.

Sarker, M. N. I., Yang, B., Tingzhi, W., Chakrovorty, A., Salam, M. A., \& Huda, N. (2020). Impacts of internal migration on poverty alleviation in Bangladesh. International Transaction Journal of Engineering, Management, \& Applied Sciences $\mathcal{E}^{\circ}$ Technologies, 11(1 1), 1-8.Available at: https://doi.org/10.14456/ITJEMAST.2020.210.

Shafi, M., Sarker, M. N. I., \& Junrong, L. (2019). Social network of small creative firms and its effects on innovation in developing countries. SAGE Open, 9(4), 215824401989824 .Available at: https://doi.org/10.1177/2 158244019898248.

Shafi, M., Zoya, L., Song, X., \& Sarker, M. N. I. (2020). The effects of transformational leadership on employee creativity: Moderating role of intrinsic motivation. Asia Pacific Management Review, 25(3), 166-176.Available at: https://doi.org/10.1016/j.apmrv.2019.12.002.

UN-OHRLLS. (2017). State of the least developed countries 2017. Special Theme: Financing the SDGs and IPoA for LDCs, The United Nations Office of the High Representative for the Least Developed Countries, Landlocked Developing Countries and Small Island (UN-OHRLLS) (pp. 1-99). New York, USA.

UNCTAD. (2016). The least developed countries report 2016: The path to graduation and beyond: Making the most of the process. Paper presented at the United Nations Conference on Trade and Development, UNCTAD/LDC/2016/Corr.1, New York, USA.

UNDP. (2017). Graduation from least developed country status. Vientiane, Laos: Lao PDR.

World Bank. (2018). Bangladesh product imports and exports (pp. 1-55). Dhaka, Bangladesh: World Bank Bangladesh Office.

Zamir, M. (2018). Moving forward with our post-LDC status. The Dhaka Tribune, p. 5. Retrieved from: https://www.dhakatribune.com/opinion/2018/03/31/moving-forward-post-ldc-status. 